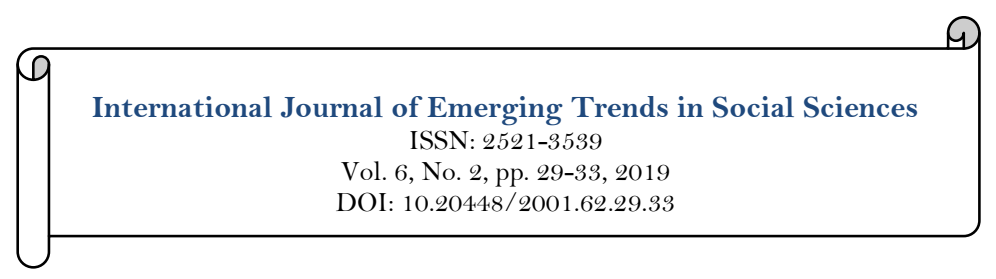

$\checkmark$ updates

\title{
Critical Discourse Analysis and the Cultivation of Critical Reading Ability
}

\section{Luo Yizhen}

Foreign Language College, Jiangxi Normal University, China. Email:932345580@qq.com

\begin{tabular}{|c|c|}
\hline Abstract & \\
\hline $\begin{array}{l}\text { As an important part of English learning, English reading should not only } \\
\text { focus on the input of language knowledge, but also the cultivation of critical } \\
\text { language awareness and critical thinking model. The traditional English } \\
\text { reading model usually includes vocabulary learning, background knowledge } \\
\text { introduction and text analysis, which is limited to letting students } \\
\text { understand the literal meaning and some implicit information of the text. } \\
\text { However, critical discourse analysis provides a broader perspective for } \\
\text { readers. Based on the theory of systemic-functional linguistics, this paper } \\
\text { takes an article from Chinese first-year college English textbooks as corpus to } \\
\text { conduct a critical discourse analysis and expose the ideology behind the text. } \\
\text { The analysis found that the article is not simply a report on a war, but also a } \\
\text { tribute to the British society. It helped England gain sympathy from the } \\
\text { international community by exposing the cruel and inhuman acts of the } \\
\text { German Nazis in Britain. At the same time, it praised the British } \\
\text { government for its strong resistance against German aggression and } \\
\text { complimented the united British people. This paper aims to explore the } \\
\text { methods of combining critical discourse analysis and reading teaching, and } \\
\text { put forward suggestions for Chinese reading teaching and the cultivation of } \\
\text { students' critical reading ability. }\end{array}$ & $\begin{array}{l}\text { Keywords: } \\
\text { Critical discourse analysis } \\
\text { Critical reading ability } \\
\text { Reading teaching. } \\
\text { Licensed: } \\
\text { This work is licensed under a } \\
\text { Creative Commons Attribution } 4.0 \\
\text { License. }\end{array}$ \\
\hline
\end{tabular}

Funding: This study received no specific financial support.

Competing Interests: The author declares that there are no conflicts of interests regarding the publication of this paper.

\section{Introduction}

As one of the four major skills (listening, speaking, reading and writing), English reading is the core component of English learning. It is not only the goal of language learning but also an important way of language acquisition. Only through a lot of reading can learners increase the all-round input of language and knowledge, expand their cultural vision, stimulate their learning interest, and thus improve their comprehensive abilities in using English. The traditional English reading model usually includes vocabulary learning, background knowledge introduction and text analysis, which is limited to letting students understand the literal meaning and some implicit information of the text. In addition, English is the language of England and America that enjoy cultural export hegemony, and a lot of western values are implied in the English texts. Traditional reading teaching makes students generally lack critical consciousness and critical reading ability, unable to distinguish the power and ideology implied in the text. This kind of plain reading cannot reveal the real intention expressed in the text and not conducive to the cultivation of students' critical thinking ability. Therefore, reading teaching must focus on cultivating students' critical reading ability.

Critical reading ability refers to critical thinking, which is a critical thinking skill. Huang Yuanshen believes that "the absence of critical thinking directly affects people's creativity, research ability and problem solving ability, and affects people's quality (Huang, 2010)." In the field of higher education, no matter for 
English majors or non-English majors, the cultivation of students' critical thinking ability is clearly stated in the syllabus. The revised English syllabus for English majors in universities in 2000 clearly stated that "the cultivation of students' thinking ability and innovation ability should be strengthened. During the process of professional courses teaching, students should be consciously trained to analyze and synthesize, abstract and summarize, analyze problems from multiple perspectives and be innovative in discovering and solving problems (English Group of Foreign Language Teaching Steering Committee of Colleges and Universities, 2000)." Critical discourse analysis (CDA) is mainly based on linguistics and combined with the research results of multiple disciplines. It takes multiple linguistic analysis methods to deeply explore the internal relations between ideology and language. Applying CDA to English texts can guide students to read texts from a critical perspective and deeply understand the potential power discourse of English texts, which has great practical significance for improving learners' comprehensive ability in using English. In this paper, the article "Report on Britain under the Bombs" which comes from New Horizon College English: Reading and Writing, a textbook for sophomores in China is taken as an example in this paper. It aims to discuss the role of CDA in English Reading for cultivating students' critical thinking and also proposes some suggestions for English reading teaching in China.

\section{Critical Discourse Analysis}

The critical discourse analysis is actually a research discipline of discourse analysis that explores the relationship between language, power and ideology lurking under the language forms. As early as 1979, English linguists put forward the concept of critical linguistics. It was not until the 1970s that the subject emerged and gradually became a new topic in modern linguistics.

\subsection{The Concept of Critical Discourse Analysis}

Critical Discourse Analysis is a method of discourse analysis proposed by Fowler et al. in the book Language and Control in 1979, which mainly conducts social analysis from the perspective of linguistics. As a new method of discourse analysis, "it studies not only what language is, but also why language is like this; it is interested not only in the meaning of words, but also in how they are produced. It aims to reveal the influence of ideology on discourse and the reaction of discourse on ideology through the superficial language form, as well as how they originate from the social structure and power relationship and how they serve that (Ding \& Liao, 2010)." Fairclough believes that "critical discourse analysis is not only the analysis of discourse, but also a systematic and interdisciplinary analysis of discourse and other components of social process. At the same time, he argues that language is inextricably linked to ideology and power (Sun, 2018)". Most scholars of critical discourse analysis believe that discourse is a form of social practice. Therefore, in the theory of CDA, it is necessary to study the connection between discourse and other elements of social practice. In research, critical discourse analysis mainly needs to focus on two aspects, power and ideology. Power refers to people's ability to take actions to achieve goals and obtain benefits, while ideology refers to people's ability to control and dominate in a certain relationship. At present, critical discourse analysis has integrated the research theories and achievements of sociology, linguistics, psychology, ethnography and other disciplines, and can combine language research and social function with relevant theories of these disciplines.

\subsection{The Method of Critical Analysis}

The main method of CDA is systematic-functional grammar. Systemic -functional grammar was founded by British linguist Halliday, who believed that the main functions of language consist of ideational function, interpersonal function and textual function. "The ideational function is that language is mainly the representation of the users' inner world, in addition, language is the logical experience summary of the external world. Interpersonal function refers to the way people express themselves for the sake of consolidating their social status and establish harmonious relationships with others. Textual function refers to the language user's ability to relate his situation to the language itself, so as to find resonance (Wang, 2017).” Transitivity system, vocabulary selection, interpersonal functional system, modality, voice and transformation are the main linguistic analysis tools used in critical discourse analysis. Apart from systemic-functional grammar, CDA can also be carried out by analyzing the genre of a text. As different genres reflect different writing purposes, authors' writing purposes can be understood through this way, and students' research interest can be fully aroused according to this clue. Students can also grasp the overall color of the text by analyzing the background of language. Since authors' writing are closely related to the social practice at that time, more social background information can be obtained by analyzing the background of language.

\section{Critical Reading Ability}

When reading a text, people want to understand the ideology hidden behind the text, so as to avoid being deceived and manipulated by the author, and then they need the corresponding critical reading ability. Therefore, critical reading is to read the discourse and reveal the hidden ideology and power relationship behind the discourse by analyzing the language form. In fact, CDA and critical reading share the same goal and essence. It can be considered that critical reading is a discourse reading process under the guidance of 
CDA theory, whose goal is to understand the implied ideological meaning of the discourse (Li, 2008). In critical reading, the reader's role will change. Specifically, it changes from language learner to textual language analyst in order to better analyze the social background behind the text and its social impact.

For a long time, the main research object of CDA is popular discourse. By using this theory to study laws and regulations, business behaviors and official reports, we can reveal people's subtle linguistic ideology, so as to interpret the behavior of the power class using language to influence people's thoughts, and finally enable people to better protect their rights. In recent years, people began to use CDA to study education, and focus on the impact of implicit ideology in foreign language teaching texts. Through research, people gradually discover the importance of cultivating students' critical reading ability, and draw the conclusion that applying CDA in English reading is helpful to build students' critical consciousness and improve students' English reading ability.

\section{Case Analysis}

In order to further analyze critical discourse, this paper takes "Report on Britain under the Bombs", a report that Germany bombed Britain during world war ii, as the object of study and analyzes the text through critical discourse. This article has been included in the national teaching materials of the 11 th five-year plan, namely, the second edition of New Horizon College English, which is specifically arranged in unit 10 of volume 2. Basically, this book is studied by freshmen in domestic universities, so it is necessary to study it.

\subsection{Transitivity Analysis}

The transitivity system proposed by Halliday is based on the experience of human life, which divides what people see, hear and do in the real world into six "processes": material, mental, rational, behavioral, verbal and existential. It intends to categorize human life experience through grammar. Choosing process and arranging the positions of participants depend largely on the ideology of users (Cai, 2008).

\begin{tabular}{l|c|c|c|c|c|c|c}
\multicolumn{1}{c}{ Table-1. Quantitative analysis of processes. } \\
\hline Process & Material & Verbal & Rational & Mental & Behavioral & Existential & Total \\
\hline Number & 9 & 4 & 6 & 5 & 9 & 0 & 33 \\
\hline Percent & $27 \%$ & $12 \%$ & $18 \%$ & $15 \%$ & $27 \%$ & 0 & $100 \%$ \\
\hline
\end{tabular}

It can be found from Table 1 that material process, behavioral process and relational process are mainly used in the text. This article is about the German bombing of Britain during the Second World War, so using material process and behavioral process is helpful to objectively describe the facts of the war.

\section{Case 1: Material Process}

"Fires burned, houses fell, gas pipes burst, and dark smoke rose from the streets. Men, women, and children felt the effect of the bombs. Radar sirens wailed, ambulances rushed from one place of agony to another, and fire fighters faced the flames hour after hour (Zhou, 2011)”.

This paragraph consists of three clauses, all of which are material processes. Material process usually describes the real situation of the development of objective things. From this case, we can see that during the Second World War, the German bombing caused heavy casualties of British people and great damage to Britain. By means of material process, the author objectively reproduced the tragic situation at that time, exposed the cruelty of Nazi Germany and won the sympathy of readers and the international community.

\section{Case 2: Behavioral Process}

"They couldn't reach up and smash the enemy planes. They had to dig quickly in cellars to rescue their friends who had been buried underneath the wreckage. They had to put out endless fire. They had to stand firm and take whatever the enemy threw at them (Zhou, 2011)".

This paragraph is composed of four behavioral process clauses. It describes the situation that the British people dug rapidly in the basement to rescue their friends buried under the ruined walls and they put out endless fires, which shows the British people's spirit of fighting together against the brutal Nazi. At the same time, this paragraph takes the rhetorical device of parallelism, and the phrase "have to" is used in the three clauses. It emphasizes that the bombing of the Nazi Germany made the British people in deep suffering, and condemns the brutal acts of the Nazi on the side.

\section{Case 3: Rational Process}

"But the English were more fortunate than the Poles in Warsaw and the Dutch in Rotterdam. They had the English Channel as a barrier against the Nazi ground forces, and they had the Royal Air Force (RAF) to battle the Nazi in the sky (Zhou, 2011)".

The second clause of the paragraph is a compound sentence which is rational process beginning with the phrase "have to". The rational process mainly reflects the relationship between things, including belonging and recognition. This sentence is belonging sentence indicating the English Channel and the Royal Air Force 
are something belonged to Britain. The paragraph suggests that Britain, unlike Poland and the Netherlands, have the English Channel as a natural barrier and a powerful air force to fight the Nazis. The author's statement emphasizes Britain's military strength, which is a kind of intimidation to the Nazis, and also implies the weak military strength of Poland and the Netherlands. At the same time, this part shows the author's national pride and inspires the British people to believe that victory will eventually belong to Britain.

Case 4: Mental Process

"Murrow knew that Britain's fate depended upon the resolution of the people in the shops and streets, the men in the pubs, the housewives, those watching for fire on the roofs, the people who had a thousand difficulties and painful things to do (Zhou, 2011)".

Mental process is the process of perception, which means "feeling", "reaction", "cognition" and "emotion". The two main participants in the mental process are the perceiver and the phenomenon. The value orientation and emotional attitude of news reporters can be seen from the mental process. This paragraph is what Edward R. Murrow, a CBS employee in Europe, thought about the war. He believed that the fate of Britain depends on the determination of the British people, as long as the British people united to fight against the Nazis and they would win the final victory. In addition to expressing Murrow's views, these words are the guide for the British people to persevere no matter how difficult it is to defend the country. It's more of a spiritual guide.

\subsection{Modality Analysis}

Halliday (2000) believes that "modality" is the intermediate state between the two poles of affirmation and negation. It is the speaker's attitude and view towards a proposition or proposal, which reflects the speaker's will or judgment.

\begin{tabular}{c|c|c|c}
\multicolumn{5}{c}{ Table-2. The use of modal verbs. } \\
\hline Modal verb & Could & Have to & Would \\
\hline Time & 3 & 5 & 2 \\
\hline Percentage & $30 \%$ & $50 \%$ & $20 \%$ \\
\hline
\end{tabular}

As can be seen from Table 2 , this article didn't use many modal verbs, because this article is a narrative text. There are ten modal verbs in the whole paper. According to the intensity of tone, "have to" and "could" belong to high modal verbs, appearing 8 times in total, while "would" belongs to middle modal verbs, appearing 2 times in total. Generally speaking, modal verbs are mainly used when describing the difficult survival of the British people and showing the belief that Britain will eventually win. The use of "Have to" highlights how difficult it is for the British people to survive under fire and reflects the brutality of the Nazis. The use of "could" was a declaration to the Nazi Germany --- Britain would definitely defeat the Nazis, it also gave the British people a shot in the arm that the British government would protect the British people. The use of high modal verbs makes the tone firm and thus uplifting.

\subsection{Transformation Analysis}

Discourse is not only a simple and random combination of information, but also a means to maximize authors' interests and achieve their purpose. That is, different expressions of the same meaning can reflect different ideologies behind it. The methods of discourse analysis commonly used in systemic functional linguistics include nominalization, passivation, quotation and indirect quotation. This article only took four direct quotations. The article quoted Edward R. Murrow's opening words on radio "This is London" twice, which comforted the British people at that time and was also a declaration for Nazi Germany. It also directly quoted the German leader Gorlin at the time ---"This is the historic hour when our air force for the first time delivered its bombs right into the enemy's heart (Zhou, 2011). "The quotation shows the arrogance of the German Nazis and the author's disdain for such remarks. Moreover, quoting the words after Britain's final victory was also a satire on Nazi Germany. The most classic quotation in the whole article was from Edward R. Murrow on the radio "Mark it down that these people are both brave and patient, that all are equal under the bomb, that this is a war of speed and organization, and that whichever political system best provides for the defense and decency of the little man will win (Zhou, 2011)." It was an inspiration to the British people, a tribute to the British political system, and a satire that the Nazis had not only disgraced their own people, but also brought war and disaster. Murrow's claim that a political system that best protects the common people and preserves their dignity will win, and Britain's eventual victory proved Murrow's prediction. Therefore, this sentence is significant and worth quoting.

Through critical discourse analysis of the whole article, it can be found that this article is not only a report on the war, but also a criticism of the German Nazi's behaviours, which helped Britain gain sympathy from the international community by exposing the cruel and inhuman acts of the German Nazi in Britain. Meanwhile, it praises the British government's tenacious resistance against German aggression and the united British people, so this article is also a tribute to the British society. If students do not have a deep 
and critical understanding of the text, they are likely to simply consider it as a report and ignore the hidden ideology.

\section{The Suggestions of Critical Discourse Analysis on Reading Teaching}

Using the theory of CDA to cultivate college students' English reading ability, it is necessary to construct a framework combining CDA and English reading. Considering the college students' cognitive ability and the requirements of college English reading course, the critical reading ability can be cultivated from three aspects: text analysis, discourse practice and social practice. From the perspective of reading stages, discourse practice analysis and social practice analysis can be carried out before reading, text analysis and discourse practice analysis can be done in reading, and social practice analysis should be carried out again after reading.

Specifically, students are guided to analyse the background of the text through discourse practice and social practice in the first stage of reading; in the process of reading, to show a variety of hints the author gave by the analysing text and the practice of discourse; in the last stage of reading, the author understands the ideology behind the text by discussing the purpose and the social impact of the text. In addition, for the sake of helping students to have a better critical understanding of the text, teachers should guide students to analyse the context of reading texts, lead students to complete the thematic analysis of reading texts, strengthen students' understanding of the reading texts and help students correctly analyse the syntax of the reading texts.

\section{Conclusion}

In recent years, society and government have put forward requirements on foreign language teaching to cultivate learners' comprehensive application ability and develop compound foreign language talents. Using the theoretical guidance of critical discourse analysis can effectively improve students' critical reading ability and enable them to actively establish the connection between language form and social context. However, this teaching theory still stays at the theoretical level in our country, and the real application of this teaching concept in English reading teaching are rare. This paper takes "Report on Britain under the Bombs", a report that Germany bombed Britain during world war ii, as the object of study and analyzes the text through critical discourse. It can be found that this article is not only a report on the war, but also a criticism of the German Nazi's behaviors, which helped Britain gain sympathy from the international community by exposing the cruel and inhuman acts of the German Nazi in Britain. Meanwhile, it describes the British government's tenacious resistance against German aggression and the united British people, so this article is also a tribute to the British society. If students do not have a deep and critical understanding of the text, they are likely to simply consider it as a report and ignore the hidden ideology. At the same time, based on the theory of critical discourse analysis, this paper puts forward some suggestions for reading teaching, which is an exploration of the critical reading teaching in China, hoping to provide some help for the development of reading teaching in China in the future.

\section{References}

Cai, X. (2008). Analysis of Clinton's inaugural speech from the perspective of critical discourse. Law and Society, 2, $236-237$. Ding, J., \& Liao, Y. (2010). A review of critical discourse analysis. Contemporary Linguistics, 3(4), 305-310.

English Group of Foreign Language Teaching Steering Committee of Colleges and Universities. (2000). English syllabus for college English major. Beijing: FLTRP, Shanghai: Foreign Language Education Press.

Halliday, M. (2000). Introduction to functional grammar (2nd ed.). Beijing: Foreign Language Teaching and Research Press.

Huang, Y. (2010). Curriculum for English majors must be overhauled---the absence of speculative ability. Foreign Language World, 1, 11-16

Li, J. (2008). Critical discourse analysis and critical reading. Journal of Sichuan International Studies University, 24(2), 88-92.

Sun, H. (2018). Enlightenment of CDA to the cultivation of students' critical thinking ability---New York times as example. Anhui Literature, 11, 143-145.

Wang, L. (2017). Critical discourse analysis and cultivation of English discourse learning ability. Journal of Hebei University of Engineering (Social Science Edition), 34, 87-89.

Zhou, J. (2011). New horizon college English 2 (2nd ed.). Beijing: FLTRP Press. 